\title{
CORPORATE SOCIAL RESPONSIBILITY DISCLOSURE AND FINANCIAL PERFORMANCE: A STATE OWNED ENTERPRISES CASE STUDY
}

\author{
Susnaningsih Muat \\ Fakultas Ekonomi Universitas Islam Negeri Sultan Syarif Kasim Riau, Indonesia \\ susnaningsih@uin-suska.ac.id \\ Agung Prayogo \\ Fakultas Ekonomi Universitas Islam Negeri Sultan Syarif Kasim Riau, Indonesia \\ agung.prayogo@,uin-suska.ac.id
}

\begin{abstract}
In today's business environment, the maximization of shareholders wealth is not the only objective of a company. By engaging in the Corporate Social Responsibility (CSR) program, companies are also responsible for the interest of stakeholders and society at large. CSR disclosure is believed to improve financial performance. In State Owned Enterprises (SOE), however, the validity of this relationship has been called into question. In this paper, the main objective is to investigate the influence of CSR disclosure on financial performance in SOE. In relation to the measurement of financial performance, this study takes into account three indicators: Return on Equity (ROE), Earning Per Share (EPS), and Net Profit Margin (NPM). In this study, data from state owned enterprises, which were listed on the Indonesian Stock Exchange from the period of 2011 to 2015, were analyzed using simple regression method. The data used in this study took the form of financial and sustainability report issued by state owned enterprises. The results show that the disclosure of CSR has a significant positive effect on ROE. The CSR disclosure also has a significant positive effect on EPS. In contrast, the disclosure of CSR has no effect on NPM. In the context of State Owned Enterprises, the research demonstrates that there is positive relationship between CSR disclosure and financial performance. This paper contributes to our understanding of state owned enterprises in Indonesia; a research area which has to date been neglected by scholars.
\end{abstract}

Keywords: Corporate Social Responsibility Disclosure, State Owned Enterprises, Return On Equity, Earning Per Share, and Net Profit Margin.

\begin{abstract}
Abstrak
Dalam lingkungan bisnis saat ini, maksimalisasi kekayaan pemegang saham bukan satu-satunya tujuan perusahaan. Dengan terlibat dalam program Tanggung Jawab Sosial Perusahaan (CSR), perusahaan juga bertanggung jawab untuk kepentingan pemangku kepentingan dan masyarakat pada umumnya. Pengungkapan CSR diyakini dapat meningkatkan kinerja keuangan. Di Badan Usaha Milik Negara (BUMN), bagaimanapun, keabsahan hubungan ini telah dipertanyakan. Dalam tulisan ini, tujuan utamanya adalab untuk menyelidiki pengarub pengungkapan TSP pada kinerja keuangan di BUMN. Sebubungan dengan pengukuran kinerja keuangan, penelitian ini mempertimbangkan tiga indikator: Return on Equity (ROE), Earning Per Share (EPS), dan Net Profit Margin (NPM). Dalam penelitian ini, data dari perusabaan milik negara, yang terdaftar di Bursa Efek Indonesia dari periode 2011 bingga 2015, dianalisis menggunakan metode regresi sederhana. Data yang digunakan dalam penelitian ini berupa laporan keuangan dan keberlanjutan yang dikeluarkan oleh perusahaan milik negara. Hasil penelitian menunjuk.kan bahwa pengungkapan CSR memiliki pengaruh positifyang signifikan terhadap ROE. Pengungkapan TSP juga memiliki pengarub positif yang signifikan terhadap EPS. Sebaliknya, pengungkapan CSR tidak berpengarub pada NPM. Dalam konteks Badan Usaha Milik Negara, penelitian menunjukkan bahwa ada bubungan positif antara pengungkapan TSP dan kinerja keuangan. Tulisan ini memberikan kontribusi untuk pemahaman kita tentang perusahaan milik negara di Indonesia; daerah penelitian yang sampai saat ini telah diabaikan oleh para sarjana.
\end{abstract}

Kata Kunci: Pengungkapan Tanggung Jawab Sosial Perusahaan, Badan Usaha Milik Negara, Return On Equity, Earning Per Share, dan Net Profit Margin

\section{PENDAHULUAN}

Recently, technological developments have had an impact on the more advanced and complex operational activities of companies. This development put a pressure on the company to be more transparent. Therefore, companies are required not only to generate profits, but also to take into account the environmental and social 
welfare of the society in conducting its operations. Awareness of this notion has grown through the triple bottom line concept that was popularized by (Elkington, 1997). This concept was famous for its 3P: People, planet, and profit, in which the performance of a company is measured using 3 criterias: economics, environment, and social.

In fact, this approach has been widely used since early 2007 as the development of a full cost accounting method that is used thoroughly by public sector companies (Neviana, 2010). In private sector companies, the implementation of Social Responsibility (CSR) is one form of Triple Bottom Line implementation. The Triple Bottom Line concept implies that firms should prioritize stakeholder interests rather than shareholders. In applying this concept, companies must adhere to activities that support 3P. People emphasize the importance of business practices that support the interests of the workforce. More specifically this concept protects the interests of labor by opposing explorations that employ minors, reasonable wage payments, safe working environments and tolerable working hours. Not only that, the concept also asks the company to pay attention to health and education for the workforce. Planet means managing well the use of energy especially on nonrenewable natural resources. Reducing waste products and recycling into safe waste for the environment, reducing $\mathrm{CO} 2$ emissions or energy use, is a common practice by companies that have adopted this concept. Profit here is more than just a gain. Profit here means creating fair and ethical trade in business. Although many factors push companies in implementing CSR initiatives, the result is, companies will ultimately benefit from such activities.

The main positive impact CSR activities can have for the company is to enhance public trust in its products. As a result, the reputation of the company will increase in the eyes of society, and people's desire to buy the company's products will increase. The profit growth will then attract investors, because the profitability is an important consideration in making investment decisions (Kusumadilaga, 2010). Beyond the benefit mentioned above, CSR activities could have further influence on financial performance.

Some research has shown that the disclosure of CSR affects financial performance as measured by Return on Assets (ROA), Return on Equity (ROE), and Net Profit Margin (NPM) (Bidhari, Salim, \& Aisjah, 2013). The relationship between CSR and financial performance, which is determined by accounting based company's performance measure and market based company's performance measure has evident (Simionescu \& Gherghina, 2014). Conversely, some studies revealed that there is no relationship between CSR and financial performance (Yaparto et al. 2013). Similar results found by Kamatra \& Kartikaningdyah (2015) (Kamatra \& Kartikaningdyah, 2015) which stated that CSR has effect effect on ROA and NPM, but CSR has no effect on ROE and EPS. Company financial performance describes the financial condition and the welfare of the company at a specific time period. Financial performance assessment is usually done through financial ratio analysis. One of the ratios usually used is a profitability ratio, which measured by Return on Equity (ROE), Earning Per Share (EPS) and Net Profit Margin (NPM).

State owned enterprises (SOE) used as the focus of this study have strategic role and functions in balancing large private forces, helping the development of small businesses/cooperatives, and fulfilling all aspects of the themes relating to CSR disclosure. SOE is believed to require a better image of society as susceptible to political influence and criticism from social activists. In addition, the company's status as a state owned, and largely owned by the government is broader in expressing CSR Disclosure. In conducting its operations, State Owned Enterprises are supervised by the House of Representatives as a representation of the people.

\section{METODE}

Sample in this research are PT. Aneka Tambang (Persero) Tbk, PT. Bank Negara Indonesia (Persero) Tbk, PT. Jasa Marga (Persero) Tbk, PT. Perusahaan Gas Negara (Persero) Tbk, and PT. Telekomonikasi Indonesia (Persero) Tbk. Data were taken from the CSR disclosure of sustainability reporting of the state-owned enterprises. Sustainability reporting contains an explanation of CSR undertaken by state-owned companies, which is then compared to the standard that has been set by the Global Reporting Initiative.

Data used in this research is using secondary data from the Annual Report and sustainability report. This study uses a simple regression analysis 
using E-Views 6 program. The models are as follows:
a. $\mathrm{Y} 1=\mathrm{a}+\mathrm{bX}+\varepsilon$
b. $Y 2=a+b X+\varepsilon$
c. $Y 3=a+b X+\varepsilon$
Description:
$\mathrm{Y} 1=$ Return On Equity (ROE)
$\mathrm{Y} 2=$ Earning Per Share (EPS)
$\mathrm{Y} 3=$ Net Profit Margin $(\mathrm{NPM})$
$\mathrm{A}=$ Constant
$\mathrm{B}=$ Regression Coefficient
$\mathrm{X}=$ CSR Disclosure

\section{Operational Definition of $V$ ariables}

Variables used in this study is the dependent variable and independent variables. The dependent variable used is the financial performance measured by ROE, NPM and EPS, while the independent variables used is CSR disclosure.

\section{Independent Variables}

Independent variables in this study are the disclosure of CSR as measured by the Corporate Social Responsibility Index (CSRI) by looking at the six performance indicators consisting of 91 indicators based on GRI version 4.0. Index obtained from the analysis of sustainable disclosure by the company. Six performance indicators contained in the GRI 4.0 which include ("Global Reporting Initiative," n.d.): 1) conomy consisting of 9 items; 2) environment consisting of 34 items; 3) employment and working comfort consisting of 16 items; 4) human rights consisting of 12 items; 5) community consisting of 11 items; and 6) product responsibility consisting of 9 indicators.

In determining the index of CSR in every company uses techniques based on tabulation checklist. An assessment conducted in measuring CSR disclosure by giving a score of 0 and 1 . Where the value 0 for items not disclosed and a value of 1 for the items disclosed by the company. If the company disclose CSR activities in full, the maximum value is achieved which is 91 items. CSR calculation formula is as follows (Gunawan \& Utami, 2008):

Description:

$$
\operatorname{CSRI}_{\mathrm{j}}=\frac{\Sigma \mathrm{Xij}}{\Sigma N j}
$$

CSRDI: Companies Corporate Social Responsibility

$$
\text { Disclosure Index }
$$

$\Sigma X i j \quad:$ Total disclosure of CSR

$\boldsymbol{\Sigma} \mathrm{Nj} \quad$ : The number of items for the company for 91 indicators

\section{Dependent Variables}

In this research the dependent variables are as follows:

\section{Return On Equity (ROE)}

According to (Rahardjo, 2010) Return on Equity (ROE) is the ratio between the net profit of the company with its own capital. This ratio shows the share of the profits derived from (or be right) own capital, and are often used by investors in the purchase of shares in a company. Formula for calculating the ROE (Rahardjo, 2010):

\section{Earning Per Share (EPS)}

$$
\mathrm{ROE}=\frac{\text { Net Income }}{\text { Total Equity }} \times 100 \%
$$

According to (Tandelilin 2007) for investors EPS information is information that is considered the most essential or useful, because it can describe the outlook for corporate earnings in the future. Information EPS of a company shows the amount of net income that is ready to share to all shareholders of the company. The amount of EPS can be in the know of the company's financial statement information. The formula for calculating Earning Per Share (EPS) is (Tandelin, 2007):

$$
\text { EPS }=\frac{\text { Net Income After Interest and Taxes }}{\text { Number of outstanding shares }} \times 100 \%
$$

\section{Net Profit Margin (NPM)}

NPM is a profitability ratio shows the company's earnings so that by knowing this ratio, the company will be able to see how much profit earned from each sale will be used as the determination of the pricing strategy (Brigham dan Houston, 2010).

$$
\mathrm{NPM}=\frac{\text { Net Income }}{\text { Sales }} \times 100 \%
$$

\section{HASIL DAN PEMBAHASAN}

\section{Normality Test}

Normality test aims to test whether a regression model, the dependent variable, independent variable, or both have a normal distribution or not. Normality test used in this study is the use Jarque Bera test to see the value of probability. If the probability value is greater than the value of the degree of error $\alpha=0.05$ then there is no problem of this research normality or in other words, the data are normally distributed. Conversely, if the probability value is less than the value of the degree of error $\alpha=0.05$, then there is a problem in this 
Susnaningsih Muat dan Agung Prayogo: Corporate Social Responsibility Disclosure and;...

research normality or in other words, the data were not normally distributed.

CSR Disclosure and ROE

Figure 1. Jarque-Bera Normality Test Result CSRROE

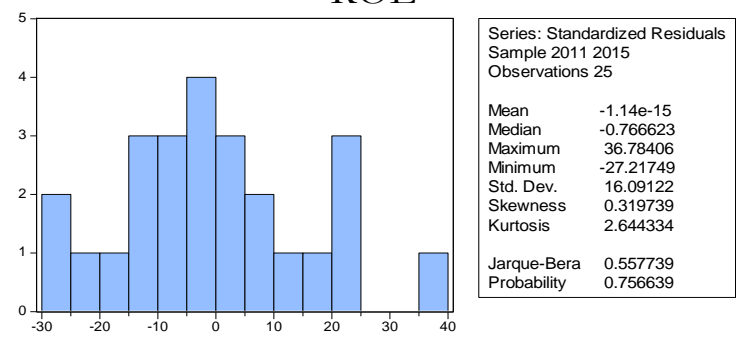

Based on figure 1, shows that independent variables disclosure of CSR and dependent variable $\mathrm{ROE}$ is already normally distributed. It can be seen from the value of Jarque-Bera amounted to 0.557739 with the probability value of 0.756639 which is larger than the degree of error 0.05 that is significantly accepted Ho.

\section{CSR Disclosure and EPS}

Figure 2 also shows that independent variables and the dependent variables EPS is normally distributed. It can be seen from the value of JarqueBera amounted to 1.462580 with the probability value of 0.481288 which is larger than the degree of error 0.05 that is significantly accepted Ho.

Figure 2. Jarque-Bera Normality Test Result CSREPS

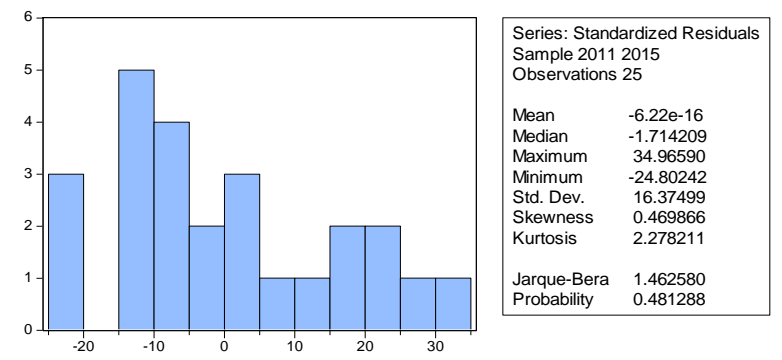

CSR Disclosure and NPM

Figure 3. Jarque-Bera Normality Test Result CSR-

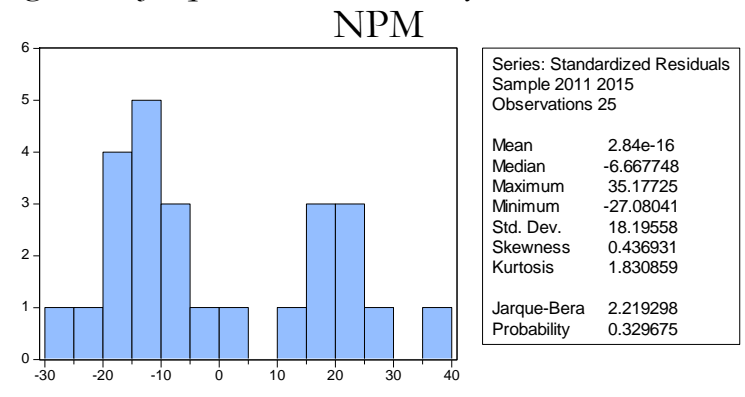

Based on Figure 3 shows that independent variables disclosure of CSR and dependent variable
NPM is already normally distributed. It can be seen from the value of Jarque-Bera amounted to 2.219298 with the probability value of 0.3229675 which is larger than the degree of error 0.05 that is significantly accepted Ho.

\section{Heterokedasticity Test}

Heteroscedasticity test aims to test whether the regression model of variants occur inequality of residual from one observation to another. If the residual is the same, it is called homoscedasticity, and if the residual is different it is called heteroscedasticity. A good regression model is homoskedasticity (Nachrowi, 2008). The method used to detect the presence of heteroscedasticity in this study is using the White test and the results of regression as in table 1 :

\section{CSR Disclosure and ROE}

Table 1. White Heteroscedaticity Test Result CSR-

$$
\text { ROE }
$$

\begin{tabular}{lclll}
\hline \multicolumn{4}{c}{ Heteroskedasticity Test: White } & \\
\hline F-statistic & 2.275403 & Prob. F(2,22) & 0.1264 \\
$\begin{array}{l}\text { Obs*R- } \\
\text { squared }\end{array}$ & 4.284997 & $\begin{array}{l}\text { Prob. } \\
\text { Square(2) }\end{array}$ & Chi- & 0.1174 \\
$\begin{array}{l}\text { Scaled } \\
\text { explained }\end{array}$ & 3.689932 & $\begin{array}{l}\text { Prob. } \\
\text { Square(2) }\end{array}$ & Chi- & 0.158 \\
\hline
\end{tabular}

From table 1 it is known that the coefficient of determination $\mathrm{Obs} * \mathrm{R} 2$ amounted of 4.284997. The probability value of the Chi-Square is 0.1174 which is greater than the $\alpha$ value of 0.05 . Because Chi-square probability value is greater than $\alpha=5 \%$, then Ho is accepted so that it can be concluded that the model has no problem of heteroscedasticity.

CSR Disclosure and EPS

Table 2. White Heteroscedasticity Test Result CSREPS

Heteroskedasticity Test: White

F-statistic $\quad 1.015707$ Prob. F(2,22) 0.3785

Obs*R-squared 2.113289 Prob. Chi-Square(2) 0.3476

Scaled explained SS 2.540661 Prob. Chi-Square(2) 0.2807

Table 2 shows that the coefficient of determination Obs * R2 amounted of 2.113289 . The probability value of the Chi-Square is 0.3476 which is greater than the $\alpha$ value of 0.05 . Because Chi-square probability value is greater than $\alpha=5 \%$, then $\mathrm{Ho}$ is accepted so that it can be concluded that the model has no problem of heteroscedasticity. 
CSR Disclosure and NPM

Table 3.White Heteroscedaticity Test Result CSRNPM

Heteroskedasticity Test: White

F-statistic $\quad 1.161189$ Prob. $\mathrm{F}(2,22) \quad 0.3316$

Obs*R-squared 2.387079 Prob. Chi-Square(2) 0.3031

Scaled explained SS 3.846535 Prob. Chi-Square(2) 0.1461

Table 3 shows that the coefficient of determination $\mathrm{Obs} * \mathrm{R} 2$ amounted of 2.387079 . The probability value of the Chi-Square is 0.3031 which is greater than the $\alpha$ value of 0.05 . Because Chi-square probability value is greater than $\alpha=5 \%$, then Ho is accepted so that it can be concluded that the model has no problem of heteroscedasticity.

Hypothesis Testing

Regression Test

Simple linear regression is used to determine the effect of independent variables on the dependent variable. In this study, a simple linear regression was conducted to determine the effect of CSR on ROE, EPS and NPM. The simple linear regression results is as follows:

Table 4.Simple Linear Regression Model Output

\begin{tabular}{lccccc}
\hline Description & Constant & Reg Coef & t-value & Significant & Result \\
\hline CSR-ROE & 7.657 & 0.2 & 1.865 & 0.015 & $\begin{array}{c}\text { Hypothesis } \\
\text { Accepted }\end{array}$ \\
CSR-EPS & 80.176 & 4.37 & 2.472 & 0.023 & $\begin{array}{c}\text { Hypothesis } \\
\text { Accepted }\end{array}$ \\
CSR-NPM & 14.18 & 0.114 & 1.157 & 0.261 & $\begin{array}{c}\text { Hypothesis } \\
\text { Rejected }\end{array}$ \\
\hline
\end{tabular}

Based on the regression results, CSR does not affect the NPM as it has significant value greater than 0.05. While CSR affect ROE and EPS as it has little significance of 0.05 . Based on the results of the regression calculation, the regression equation are as follows:

$$
\begin{array}{ll}
\mathrm{ROE} & =7.657+0.200 \mathrm{CSR} \\
\mathrm{EPS} & =80.176+4.370 \mathrm{CSR} \\
\mathrm{NPM} & =14.18+0.114 \mathrm{CSR}
\end{array}
$$

Overall, the interpretation of the regression equation are as follows: 1) the regression coefficient effect of CSR on ROE shows a value of 0.200 with a significance value of 0.015 . The value of 0.015 significance is less than 0.05 , so CSR has an influence on ROE. The first hypothesis which predict that CSR positive effect on ROE at stateowned enterprises listed on the Stock Exchange in the 2011-2015 period is accepted. The sign of regression coefficient is positive so that the increase of CSR disclosure will increase the value of the company's ROE. Improved disclosure of
CSR by 1 point will increase the company's ROE of 0.200 points; 2 ) the regression coefficient effect of CSR disclosure on EPS shows a value of 4.370 with a significant value of 0,023 . The value of 0,023 is less than 0,05 therefore CSR disclosure has an influence on EPS. Consequently, the second hyphotesis which predict that CSR disclosure has a positive impact on EPS at state-owned enterprises listed on the Stock Exchange in the 2011-2015 period is accepted. The sign of regression coefficient is positive so that the increase of CSR disclosure will increase the value of the company's ROE. Improved disclosure of CSR by 1 point will increase the company's ROE of 0.437 points; and $3)$ the regression coefficient effect of CSR disclosure on NPM shows a value of 0.114 with a significant value of 0,261 . The value of 0,261 is greater than 0,05 therefore CSR disclosure has no influence on NPM. Therefore the third hyphotesis which predict that CSR disclosure has a positive impact on NPM at state-owned enterprises listed on the Stock Exchange in the 2011-2015 period is rejected. The sign of regression coefficient is positive so that the increase of CSR disclosure will increase the value of the company's NPM, but insignificantly. Improved disclosure of CSR by 1 point will increase the company's ROE of 0.472 points.

Effect of Corporate Social Responsbility(CSR) Disclosure on Financial Performance as Measured by Return On Equity (ROE) in The State Owned Enterprise Companies Listed in Indonesia Stock Exchange for the Periode of 2011-2015

Implementation of CSR is believed to enhance the company's financial performance, which investors tend to invest in companies that carry out CSR activities. Because for investors, companies that undertake CSR activities have the potential to generate profits greater than those without, so that future companies will be able to improve its financial performance. The CSR implementation will cause the company to incur additional costs which are quite amount. Expenses due to these costs will certainly affect the profitability of the company. However, this activity will also cause a positive image of the company in the eyes of society so that the loyalty of the people to buy these products increased because of the positive image and social costs incurred for CSR will affect the 
profitability of the company (Rosiliana et al., 2014). $\mathrm{ROE}$ is the ratio between the net profit of the company with its own capital. This ratio shows the share of the profits derived from (or be right) own capital, and are often used by investors in the purchase of shares in a company.

The results of this research show that the variables of CSR disclosure provides regression coefficient 0.200 with a significant level of 0.015 which means providing positive and significant impact on ROE. Therefore, the first hypothesis which says CSR positive effect on ROE accepted. It can be concluded that the more publicized CSR activities, the company's ROE will also increase. The results of this research was supported by some previous researchers that produced that disclosure of CSR affect the ROE (Candrayanthi \& Saputra, 2013), and (Bidhari et al., 2013).

\section{Effect of Corporate Social Responsbility (CSR)} Disclosure on Financial Performance as Measured by Earning Per Share (EPS) in The State Owned Enterprise Companies Listed in Indonesia Stock Exchange for the Periode of 2011-2015

CSR can have a positive impact for the company, where the company's CSR activities can enhance public trust in the company's products so that the reputation of the company also increased in the eyes of society. This will significantly affect its financial performance. In other words, the better the company discloses CSR, it will build a good corporate image in the eyes of consumers. Consumers will have a good view because the company has paid attention to the public interest, so consumers do not mind using the product. The more consumers use the product, it will increase the company's sales (Ajilaksana \& Kiswara, 2011).

According to (Tandelilin, 2010) EPS is considered as the most basic information, because it can describe the outlook for corporate earnings in the future. EPS information shows the amount of net profit the company is ready to share for all shareholders of the company. The amount of EPS can be seen in the company's financial statements. This research indicates that CSR disclosure calculated by CSDI (Corporate Social Disclosure Index) is shown to have a positive influence on EPS. This is indicated by the result of CSR disclosure statistic test which gives regression coefficient of 4,370 with significant level of 0.023 which means CSR disclosure has positive and significant influence to EPS. More and more companies disclose and perform CSR activities will result in higher levels of company sales. In the end, high sales will increase profits. Profit increases then EPS value will increase. This suggests that the second hypothesis is accepted. This research is supported by the research of Priyanka 2013 and (Kamatra \& Kartikaningdyah, 2015), which shows that CSR disclosure has a positive effect on EPS.

Effect of Corporate Social Responsbility (CSR) Disclosure on Financial Performance as Measured by Net Profit Margin (NPM) in The State Owned Enterprise Companies Listed in Indonesia Stock Exchange for the Periode of 2011-2015

CSR covers three main dimensions, namely profit for the company, empowering communities and preserve the nature. Some examples of CSR activities usually done is a scholarship program, the establishment of target schools, partnerships with SMEs, health and safety, environmental protection such as reforestation and others. Communities and stakeholders can give a positive response to companies that engage in CSR activities. Positive responses were given by the public and stakeholders in the form of trust and acceptance of the products produced by the company, as a result, can improve the operation of the company, and this will have implications on the company's improved financial performance (Sitohang, 2012). NPM is a profitability ratio shows the company's earnings so that by knowing this ratio, the company will be able to see how much profit earned from each sale will be used as the determination of the pricing strategy (Brigham and Houston, 2010).

The result of this research is variable CSR with a regression coefficient of 0.114 with a significance level of 0261, whose value is greater than 0.05 . This shows that CSR has no influence on NPM. Thus the third hypothesis stating CSR positively affects NPM is rejected. CSR does not affect the financial performance of State Owned Enterprise Company as measured by NPM. That is, the CSR activities undertaken by the company, was not shown to have a significant impact on the financial performance of the company. The results of this study indicate that the ethical behavior of companies in the form of CSR activity on the surrounding environment is not getting a response 
from the public. Companies do not need to do CSR activities to shape consumer response in the form of trust and acceptance of the products produced by the company. So, people will still receive the products produced by state-owned companies, although the state-owned company does not undertake CSR activities in the surrounding environment of the state-owned company. The results of this study are supported by several researchers who showed that CSR does not have an influence on the NPM, namely (Mustafa \& Handayani, 2014)), and (Candrayanthi \& Saputra, 2013).

\section{PENUTUP}

\section{Simpulan}

From the results of data analysis using E-Views 6 program, hypothesis testing, and discussion, it can be concluded from this research that CSR has a positive impact on financial performance as measured by ROE at state-owned enterprises listed on the Stock Exchange 2011-2015 period. Because it has a value $t_{\text {value }} 1.865>t_{\text {table }} 1.713$ with significant value of 0.015 , which is significantly smaller than the value of the significant rate used $(0.015<0.05)$. CSR also has a positive effect on financial performance as measured by EPS on state-owned enterprises listed on the Stock Exchange 20112015 period. Because it has a value $t_{\text {value }} 2.472>t_{\text {table }}$ 1.713 with significant value of 0.023 , which is significantly smaller than the value of the significant rate used $(0.023<0,05)$. While CSR has no effect on the financial performance as measured by NPM on state-owned enterprises listed on the Stock Exchange 2011-2015 period. Because it has a value $t_{\text {value }} 1.157<\mathrm{t}_{\text {table }} 1.173$ with significant value of 0.261 , which is significantly greater than the value of the significant rate used $(0261>0.05)$.

\section{DAFTAR PUSTAKA}

Ajilaksana, I., \& Kiswara, E. (2011). Pengarub Corporate Social Responsibility Terhadap Kinerja Keuangan Perusabaan. Universitas Diponegoro. Retrieved from http://eprints.undip.ac.id/29067/

Balabanis, G., Phillips, H. C., \& Lyall, J. (1998). Corporate social responsibility and economic performance in the top British companies: are they linked? European Business Review, 98(1), 25-44.
Bidhari, S. C., Salim, U., \& Aisjah, S. (2013). Effect of corporate social responsibility information disclosure on financial performance and firm value in banking industry listed at Indonesia stock exchange. European Journal of Business and Management, 5(18), 39-46.

Brigham, Eugene F and Houstan, Joel. (2010). Dasar-dasar Manajemen Keuangan. Jakarta: Penerbit Salemba Empat.

Candrayanthi, A. A. A., \& Saputra, I. D. . D. (2013). Pengaruh Pengungkapan Corporate Social Responsibility Terhadap Kinerja Perusahaan (Studi Empiris pada Perusahaan Pertambangan di Bursa Efek Indonesia. EJournal Akuntansi Universitas Udayana, 4(1), 141-158.

Cho, C. H., \& Patten, D. M. (2007). The role of environmental disclosures as tools of legitimacy: A research note. Accounting, Organizations and Society, 32(7-8), 639-647. https://doi.org/10.1016/j.aos.2006.09.009

Clarkson, M. E. (1995). A stakeholder framework for analyzing and evaluating corporate social performance. Academy of Management Review, 20(1), 92-117.

Cormier, D., \& Gordon, I. M. (2001). An examination of social and environmental reporting strategies. Accounting, Auditing \& Accountability Journal, 14(5), 587-617. https://doi.org/10.1108/EUM0000000006 264

Elkington, J. (1997). Cannibals with Forks The Triple Bottom Line of 21th Century Business. Capstone Publishing Ltd, Oxford. Retrieved from http://appli6.hec.fr/amo/Public/Files/Do cs/148_en.pdf

Ghozali, I., \& Chariri, A. (2007). Teori Akuntansi. Semarang: Badan Penerbit Universitas Diponegoro.

Global Reporting Initiative. (n.d.). Retrieved April 5, 2017, from https://www.globalreporting.org/Pages/de fault.aspx

Gunawan, B., \& Utami, S. S. (2008). Peranan Corporate Social Responsibility Dalam Nilai Perusahaan. Jurnal Akuntansi Dan Keuangan, 7(2), 174-185.

Jensen, M. C., \& Meckling, W. H. (1976). Theory of the firm: Managerial behavior, agency costs and ownership structure. Joumal of Financial Economics, 3(4), 305-360. 
Susnaningsih Muat dan Agung Prayogo: Corporate Social Responsibility Disclosure and;...

https://doi.org/10.1016/0304-

405X(76)90026-X

Kamatra, N., \& Kartikaningdyah, E. (2015). Effect corporate social responsibility on financial performance. International Journal of Economics and Financial Issues, 5. Retrieved from http://search.proquest.com/openview/41e 91d93199a01d79862a3be7f9c8e71/1?pqorigsite $=$ gscholar\&cbl $=816338$

Kusumadilaga, R. (2010). Pengaruh Corporate Social Responsibility Terbadap Nilai Perusabaan Dengan Profitabilitas Sebagai Variabel Moderating (Studi Empiris Pada Perusahaan Manufaktur Yang Terdaftar Di Bursa Efek Indonesia). Perpustakaan FE UNDIP. Retrieved from http:/ / eprints.undip.ac.id/22572/

Lako, A. (2011). Dekonstruksi CSR dan Reformasi Paradigma Bisnis \& Akuntansi.

Mansur, S. (2012). Pelaporan Corporate Social Responsibility Perbankan Syariah Dalam Perspektif Syariah Enterprise Theory (studi Kasus Pada Laporan Tabunan PT Bank Syariah Mandiri). Retrieved from http://repository.unhas.ac.id/handle/12345 $6789 / 1964$

Moenna, R. (2014). Corporate Social Responsibility And Financial Performance: An Empirical Analysis on EU's top fifty Listed Companies. Erasmus School of Economics, Erasmus University Rotterdam. Retrieved from http://citeseerx.ist.psu.edu/viewdoc/downl oad?doi=10.1.1.918.6053\&rep=rep1\&type $=\mathrm{pdf}$

Moir, L. (2001). What do we mean by corporate social responsibility? Corporate Governance: The International Journal of Business in Society, 1(2), $16-22$.

Mustafa, C. C., \& Handayani, N. (2014). Pengaruh Pengungkapan Corporate Social Responsibility Terhadap Kinerja Keuangan Perusahaan Manufaktur. Jurnal Ilmu \& Riset Akuntansi, 3(6), 1-16.

Nachrowi, D. dan Hardius Usman. 2006. "Pendekatan Populer dan Praktis EKONOMETRIK Untuk Analisis Ekonomi dan Keuangan", FEUI: Jakarta.

Neviana, N. (2010, October 19). Triple Bottom Line: Lebih dari Sekadar Profit. Retrieved July 31, 2017, from https://swa.co.id/swa/my-article/triplebottom-line-lebih-dari-sekadar-profit
Prabawati, G. A. D. (2016). Disclosure of Corporate Social Responsibility in the Annual Sustainability Report Based Global Based on Global Reporting Initiative Guidelines (comparative Study Between Time of Pt. Holcim Report Period 20092013). Jumal Ilmiah Mahasiswa FEB, 3(2). Retrieved from http://jimfeb.ub.ac.id/index.php/jimfeb/ar ticle/view/2011

Rahardjo, Budi. (2010). Laporan Kenangan Perusahaan. Gadjah Mada University Press : Yogyakarta

Rosiliana, K., Yuniarta, G. A., AK, S., Darmawan, N. A. S., \& others. (2014). Pengaruh corporate social responsibility terhadap kinerja keuangan perusahaan (studi empiris pada perusahaan lq45 di bursa efek indonesia periode 2008-2012). JIMAT (Jurnal Ilmiah Mahasiswa Akuntansi S1), 2(1). Retrieved from

http://ejournal.undiksha.ac.id/index.php/S $1 \mathrm{ak} /$ article/view/3452

Simionescu, L. N., \& Gherghina, S. C. (2014). Corporate social responsibility and corporate performance: empirical evidence from a panel of the Bucharest Stock Exchange listed companies. Management \& Marketing, 9(4), 439.

Suharto, Edi (2008), Corporate Social Responsibility: What is and Benefit for Corporate. Makalah Yang Disajikan Pada Seminar Dua Hari, Corporate Social Responsibility: Strategy, Management, and Leadership, HotelAryaduta. Jakarta 13-14 Februari 2008.

Tandelin, Eduardus. (2007), Analisis Investasi dan Manajemen Portofolio. BPFE:Yogyakarta.

Yaparto, M., Frisko, K. D., Eriandani, R., (2013)., Influence of Corporate Social Responsibility Against Financial Performance on Manufactured Companies Listed in Indonesia Stock Exchage 2010-2011., Student Scientific Journal Surabaya University, 2(1), 1-19 